\title{
PRASANGKA DAN UJARAN KEBENCIAN SIBER: PERAN POLA KOMUNIKASI DARING DAN ALGORITMA MEDIA SOSIAL (Ruang Gema dan Gelembung Informasi)
}

\author{
Mardianto \\ Jurusan Psikologi FIP Universitas Negeri Padang \\ mardiantopsi@fip.unp.ac.id
}

\begin{abstract}
Abstrak
Artikel ini membahas tentang ujaran kebencian siber yang dipengaruhi oleh sikap prasangka individu, dan karakteristik komunikasi di ruang online serta algoritma media sosial. Artikel ini mengunakan pendekatan kajian kepustakaan dengan mencari referensi teori yang relefan dengan kasus dan permasalahan perilaku siber khususnya ujaran kebencian. Hasil analisis dari kajian teori dan hasil penelitian terbaru pada jurnal ilmiah menyebutkan bahwa prasangka kelompok dan perilaku ujaran kebencian di media sosial adalah akibat dari paparan informasi yang bersifat propokatif dan berulang ulang dalam gelembung informasi masing masing individu yang diperolehnya selama berselancar di dunia maya. Selain itu juga diakibatkan oleh keterbatasan pola komunikasi di media sosial yang hanya satu arah atau perspektif dan bersifat self-interest.
\end{abstract}

Kata Kunci: Prasangka, Ujaran Kebencian Siber, Komunikasi Daring, Propaganda Siber.

\begin{abstract}
This article discusses the cyber hate on social media that are influenced by prejudice, characteristics of online communication and cyber propaganda. This article uses a literature review approach by looking for references to theories that are relevant to the cases and problems of cyber behavior, especially speech hate. The results of the analysis of theoretical studies and the results of the latest research in scientific journals state that group prejudice and hate speech behavior on social media are the result of exposure to information that is both propocative and repetitive or echo chamber effect in each filter bubble that he obtained during surfing in cyberspace. In addition, it is also caused by the limitations of communication patterns on social media which are only one direction or perspective and are self-interest.
\end{abstract}

Keywords: Prejudice, Cyber hate, Online Communication, Algoritma Social Media

Kehadiran media sosial telah membawa perubahan besar terhadap perilaku dan pola komunikasi individu, dimana keberadaannya menggantikan fungsi surat, telepon dan komunikasi langsung tatap muka dengan menciptakan jejaring kemonikasi antar individu melalui perangkat aplikasi yang diinstalkan pada peralatan eletronik atau gawai seperti komputer yang terhubungan dengan internet dan ponsel peribadi. Para pengguna media sosial biasanya disebut sebagai warga netizen, dapat berkomunikasi dengan keluarga, teman, atasan idola dan publik figur bahkan dengan pejabat pemerintahan sekali pun, selain itu juga dapat dengan cepat mengakses informasi dari berbagai sumber dari berbagai belahan dunia hanya dengan alat telekomunikasi yang ada di tangannya dimana pun ia berada.
Hootsuite (2017) menjelaskan penguna internet pada tahun 2017 sudah mencapai sebanyak 3,8 miliar, dengan 2,9 milyarnya aktif menggunakan media sosial, tak kurang dari, pengguna media sosial terus meningkat sekitar 1 jutaan orang perhari pengguna media sosial terus meningkat dengan estimasi ada 14 orang yang bikin media sosial baru setiap detik di dunia. Sedangkan dari 2,9 milyar pengguna media sosial yang ada sekitar 2,6 milyarnya mengakses akun media sosial mereka melalui ponsel, sedangkan penggunaan internet melalui laptop atau desktop terus menurun hampir $20 \%$ termasuk penggunaan media tablet, dimana jumlahnya pengunaannya hanya $43 \%$ dari jumlah keseluruhan pengguna internet, karena orang semakin terbiasa "go online" dengan layar smartphone yang lebih kecil. Sementara itu pengguna internet di Indonesia saat ini sudah 
mencapai 132,7 juta orang. dari angka tersebut, 97 persennya menggunakan internet untuk mengakses jejaring sosial. Sedangkan situs jejaring sosial yang paling banyak diakses adalah facebook dan twitter. Indonesia menempati peringkat 4 pengguna facebook terbesar setelah Brazil, dan India dan USA.

Bedasarkan data tersebut di atas tentu kita dapat membayangkan bagai mana media sosial khususnya jejaring sosial setiap saat dan setiap waktu tidak dapat tidak akan mempengaruhi pola dan dinamika perilaku penggunanya baik melalui interaksi dan komunikasi yang dibanggun dalam jejaring sosial tersebut, maupun pengaruh persuasif dari setiap berita dan informasi yang dikirim atau yang diakses melalui blog, wiki, podcast, forum online lainnya.

Ada dua tipe dari pola perilaku online (onlinedisinhibition) individu, yaitu benign disinhibition yaitu pola perilaku online yang menunjukan sisi ramah, altruistik atau sifat protagonist individu dan tonixc disinhibition yang menunjukan sisi kasar atau sifat antagonist yang dimiliki individu (Suler (dalam Febriawan dkk., 2014). Beberapa penelitian bahkan menemukan bahwa kadang perilaku komunikasi dan respon individu di media sosial jauh berbeda dari perilaku komunikasi kesehariannya seperti dalam interaksi lansung tatap muka. Individu bisa saja lebih bebas berekspresi, dan berpendapat, dalam mengungkapan tentang apa yang mereka pikirkan, apa yang mereka rasakan, kadang malah terkesan tidak asertif, narsis, dan arogan, karena merasa tidak dibebani oleh ketrikatan norma dan nilai-nilai yang berlaku dalam interaksi lansung tatap muka.

Selain itu layanan media sosial yang tidak membatasi penggunanya, baik dari segi usia dan jenis kelamin, status sosial dan pendidikan mengakibatkan para netizen bebas mengekspresikan perasaannya di akun pribadinya masing masing. Hal tersebut membuat gaya dalam proses bertutur mereka sering kali mewakili status dan identitas sosial masing masing. Kondisi seperti ini kadang tidak disadari oleh para pengguna media sosial sehingga sengaja ataupun tidak banyak yang menggunakan kata-kata atau kalimat bernuansa menyindir, mencemooh, menghina, bahkan lebih parah lagi sampai menuduh, mengancam, menuntut, sehingga pernyataan tersebut menyinggung perasaan dan meyerang harga diri lawan bicara sehinga melahirkan konflik sosial karena melahirkan pengikut yang disebut dengan lover lawan pembenci yang disebut dengan hater (Bada dan Sasse, 2014).

Hal tersebut tidak jarang berujung pada konflik individu di dunia maya atau di jejaring sosial diakibatkan oleh respon komunikasi yang melahirkan emosi permusuhan atau propokatif yang tendensius kebencian terhadap satu individu atau kelompok lain. Respon-respon tersebut dapat berupa komentar, pesan, tuwitan di tweeter, update ststus di beranda facebook, atau tulisan di laman web, bertujuan untuk mengkritik bahkan kadang menjatuhkan, termasuk berbagai opini dan pemikiran serta sikap yang ditunjukan sebagai tanggapan terhadap isu-isu yang sedang virall. (Martellozzo dkk., 2017).

Menurut (Febriawan dkk., 2014) pernyataan atau ungkapan kritik yang bersifat merendahkan, menghina dan menghujat pada interkasi online antar individu dimedia sosial akan memancing situasi memanas, suasana itu disebut dengan istilah flame, sedang perilakunya disebut flaming dan orang orang yang melakukanya disebut haters. Perilaku haters muncul akibat rasa tidak senang kepada seseorang atau kelompok tertentu dengan perilaku, gaya hidup, pernyataan dan kinerjanya ataupun aktifitas seseorang atau kelompok tersebut. Perilaku haters tersebut untuk selanjutnya dalam artikel ini digunakan istilah dengan ujaran kebencian siber. Ujaran kebencian siber adalah merupakan bentuk perilaku penyebaran pesan bernada kebencian melalui media internet dan situs jejaring sosial, pembuatan konten melalui, situs, blog, pesan instan online seperti; face book, whatsaap, line dan sebagainya baik melalui handpone maupun computer.

Ujaran kebencian siber dapat saja dilakukan oleh diri peribadi atau pun sekelompok orang yang membenci individu atau kelompok lainnya, bahkan dengan tujuan memengaruhi orang lain dan atau pun kelompok lainnya untuk merasakan hal yang sama yakni membenci serta berharap figure orang atau komunitas yang dibenci akan celaka, hina dan hancur kualitas dan harga dirinya. (Williams dan Pearson, 2016). Para pelaku ujaran kebencian siber melakukan penyebaran pesan, opini atau pun informasi baik yang berasal dari redaksi sendiri ataupun orang lain yang ia bagikan lagi sebagai bentuk dukungan dan pesan dan opini tersebut yang tujuannya adalah untuk mempengaruhi, mengajak secara langsung ataupun tidak langsung untuk tidak menyukai ataupun membenci bahkan memusuhi 
seseorang atau kelompok tertentu yang dikategorikan sebagai musuh ataupun ancaman.

Hal di atas diperparah oleh algoritma-algorima yang yang diterapkan pada platform-platform mainstream media sosial yang kerap di gunakan oleh netizen. Salah satu algoritma yang dapat berimplikasi pada terbentuknya situasi yang membuat individu terpolarisasi pada kelompok kelompok eklusif yang kadang tertutup dalam gelombang informasi masing-masing atau biasa dikenal denganfilter bubble. Netizen akan diarahkan kepada keberpihakan terekstrim pada sesuatu hal karena algoritma yang ada pada fasilitas media sosial akan mengasumsikan bahwa seorang netizen akan suka terhadap hal tersebut. Algoritma ini merekam pola perilaku netizen melalui aktivitas like, comment, dislike, reply, follow, unfollow hingga block (Bozdag, 2015).

Berdasarkan hal tersebut media sosial menghadirkan dua bentuk pola interaksi warga netizen, yaitu selain mendekatkan antar sesama penguna namun juga sekaligus dapat saja menjauhkan dan menjadikannya terkotak-kotak sesuai dengan karakteristik kelompok masing masing. Polarisasi kelompok akan terbentuk oleh terpaan informasi yang didapat oleh individu selama ia berselancar di dunia maya dan informasi itu bersifat hanya satu arah atau perspektif. Individu sebagai masyarakat internet atau netizen memiliki kecenderungan untuk menyaring setiap informasi yang masuk baik dalam bentuk bacaan, visual, audio visual maupun konten lainnya sesuai dengan apa yang sudah diyakini, dan keyakinan tersebut akan semakin kuat ketika individu terpapar informasi yang sama dan berulang, Berdasarkan permasalahan di atas, maka artikel ini mencoba untuk mengkaji lebih dalam dinamika perilaku ujaran kebencian siber yang di dasari oleh prasangka dan hal yang berhubungan karateristik komunikasi online serta hal yang berasal dari logaritma layan media sosial tersebut.

\section{Ujaran Kebencian Siber}

Ujaran kebencian adalah istilah untuk menjelaskan perilaku pada haters atau pembenci di dunia siber yang pada dasarnya mengacu pada pesan kebencian secara online, dimana penggunaan teknologi informasi untuk menyebarkan pesan anti terhadap suku, agama dan ras tertentu, yang bersifat fanatik, ekstrimis bahkan mengarah pada tindakan menteror individu atau kelompok lain (Jubany dan Roiha, 2015).
Walters dan Brown (2016) dalam laporan ristenya pada Equality and Human Rights Commission tentang perilaku ujaran kebencian dan hate crime di Inggris mengidentifikasikan perilaku membenci online tersebut berupa: "act intended or likely to stir up hatred, assault, criminal damage, harassment, stalking, threatening or abusive behavior.

Bentuk perilaku online lainya yang dapat dimasukan sebagai bentuk ujaran kebencian adalah flaming. (Nitin dkk., 2012) menjelaskan bahwa bentuk lain dari ujaran kebencian siber berupa komunikasi online yang meningkatkan ekspresi emosi bermusuhan, yang disebut flaming. Seringkali komunikasi secara online jarang mempertimbangkan persaan orang seperti komunikasi ofline secara tatap muka, sehingga memancing suasana panas. Penelitiannya melihat lebih dekat konteks sosial di mana flaming terjadi, tapi juga latar belakang sosial, rasa atau etnis budaya, orientasi seksual, agama, idiologi dan politik serta status sosial.

Ujaran kebencian siber berbeda dengan Cyberbullying, yang merupakan perilaku intimidasi dan kekerasan melalui internet dimana seorang, dihina, diintimidasi, atau dipermalukan oleh individu lain melalui media internet, teknologi digital atau telepon seluler, yang pada umumnya ditujukan langsung kepada individu dan antar individu. Perilaku cyberbullying didasarkan oleh perasaan dominan dan berkuasa terhadap individu yang biasanya lebih memiliki kekurangan power atau berada pada posisi lemah. Lebih jauh lagi cyberbullying bermaksud untuk melukai merusak milik dan mengganggu secara secara nyata melalui ancaman dan intimidasi khususnya pada seorang anak atau individu.

Dalam Surat Edaran (SE) Kapolri soal penanganan ujaran kebencian atau hate speech nomor SE/06/X/2015, dan telah dikirim ke Kepala Satuan Wilayah (Kasatwil) seluruh Indonesia. Pada Nomor 2 huruf (f) SE itu, disebutkan bahwa "ujaran kebencian dapat berupa tindak pidana yang diatur dalam Kitab Undang-Undang Hukum Pidana (KUHP) dan ketentuan pidana lainnya di luar KUHP, yang berbentuk antara: a). Penghinaan, b). Pencemaran nama baik, c). Penistaan d). Perbuatan tidak menyenangkan, e). Memprovokasi, f). Menghasut, g). Menyebarkan berita bohong dan semua tindakan di atas memiliki tujuan atau bisa berdampak pada tindak diskriminasi, kekerasan, penghilangan nyawa, dan atau konflik sosial". 
Selanjutnya, pada huruf (g) disebutkan bahwa ujaran kebencian sebagaimana dimaksud di atas bertujuan untuk menghasut dan menyulut kebencian terhadap individu dan atau kelompok masyarakat dalam berbagai komunitas yang dibedakan dari aspek; a). Suku, b). Agama, c). Aliran keagamaan, d). Keyakinan atau kepercayaan, e). Ras, f). Antargolongan, g). Warna kulit, h). Etnis, i). Gender, j). Kaum difabel, k). Orientasi seksual.

Berdasarkan targetnya pesan kebencian yang disebarkan oleh hater biasanya mengarah pada:

a. Hasutan pesan kebencian dan ketidak sukaan pada keyakinan dan agama orang lain

b. Hasutan kebencian terhadap perilaku dan orientasi seksual orang lain.

c. Hasutan pesan kebencian pada kelompok sosial, suku dan ras tertentu.

d. Hasutan kebencian pada kelompok atau pemimin politik tertentu.

e. Hasutan kebencian pada publik figur yang memiliki popularitas atau profesi tertentu.

f. Hasutan pada kebencian terhadap pandangan pemikiran yang disampaikan oleh sesorang (Kuwado, 2015).

Perilaku menyebarkan pesan kebencian kepada individu atau kelompok tertentu tersebut dimotivasi oleh banyak faktor diantaranya sosial-ekonomi,dan budaya. Meski pun begitu persoalan etnis bukanlah masalah mendasar, melainkan pada aspek sosial karena adanya kesalahpahaman bahwa keberadaan orang asing akan berdampak pada keberlangsungan jaminan sosialnya dan rasa keterancaman oleh kelompok pendatang/migran (Callens, 2015).

\section{Prasangka Siber}

Secara etimologis, prasangka berasal dari kata Latin yaitu praejudicium yang menurut Allport tokoh penelitian prasangka sosial, definisi singkatnya adalah berpikir buruk terhadap orang lain tanpa jaminan yang cukup. Dalam sumber lain prasangka adalah: sikap negatif terhadap kelompok yang didefinisikan secara sosial dan terhadap setiap orang yang dianggap sebagai anggota kelompok itu. Prasangka juga diartikan sebagai sikap permusuhan atau permusuhan terhadap seseorang yang menjadi anggota kelompok, hanya karena ia termasuk kelompok tertentu, dan karena itu diduga memiliki kualitas yang tidak pantas yang dianggap berasal dari kelompok tersebut (Ashmore dan Allport dalam Ngwayuh, 2017).

Prasangka dapat diekspresikan secara terbuka dan langsung atau dengan cara yang halus, tidak langsung dan sembunyi-sembunyi dalam pemikiran atau perilaku yang bersifat rasisme, seksisme, sikap anti-imigran, anti-semitisme dan banyak prasangka lainnya dengan demikian bukanlah sifat-sifat pribadi, tetapi sikap sosial yang harus dipahami melalui konteks orang yang memegangnya. Salah satu contoh penting dari yang terakhir adalah penolakan atau tidak simpati pada kelompok out group, atau melebih-lebihkan perbedaan budaya yang ada.

Prasangka dibuat melalui proses tiga tahap yang melibatkan: 1) kategorisasi, 2) stereotip dan 3) penilaian (afektif priming). Langkah pertama adalah kategorisasi adalah proses kognitif mendasar yang terjadi secara otomatis dan membantu individu memahami informasi mengelompokan dan menilai pada karakteristik yang melekat yang disebut sebagai kategori sosial. Kategori in-group-out-group berdasarkan perbedaan gender, jenis kelamin, etnis suku dan ras, agama, orientasi seksual, pilihan politi dan lain sebagainya. Langkah kedua stereotype yaitu atribut karakteristik tertentu kepada orang-orang atas dasar keanggotaan grup mereka. Stereotip melibatkan generalisasi tentang sekelompok orang, mengaitkan karakteristik identik dengan mereka semua meskipun sebenarnya pada tataran individu mereka sangat berbeda. Tahap ketiga dari pembentukan prasangka adalah orang-orang yang telah kami kategorikan ke dalam kelompok-kelompok dan stereotip akhirnya dievaluasi secara positif atau negatif. Sebagai aturan, anggota masyarakat cenderung menilai anggota ingroup mereka secara positif dan anggota kelompok luar yang diidentifikasi secara negatif (Guimond dkk., 2003). Karakteristik interasi dan komunikasi di dunia siber membawa perkembangan baru dalam memehami persepsi dan prasangka antar kelompok sosial serta perilaku diskriminasi individu. Hal ini dikarenakan interaksi dalam dunia siber hingga saat ini sebagian besar berbasis teks, sehingga mereka yang terlibat dalam komunikasi siber kekurangan banyak informasi seperti yang disampaikan secara tradisional atau tatap muka. Bahkan tak jarang pesan yang sampai dari komunikator hanya berupa audio, seperti nada, volume, gerakan, hanya sedikit informasi yang didapat dari ekspresi wajah serta karakteristik komunikator seperti usia, ukuran, jenis kelamin, ras / etnis, atau stigma fisik. (O’Hara dan Stevens, 2004).

Spears (dalam O'Hara dan Stevens, 2004) menyatakan bahwa dalam interaksi siber 
identifikasi kelompok dapat diperkuat secara anonim, yang dimediasi oleh komunikasi online pada gilirannya dapat berkontribusi dalam meningkatkan prasangka antar kelompok. Setiap kelompok mengembangkan identitas berdasarkan, perbedaan perspekti dan merasa lebih baik daripada kelompok lain. Dinding konseptual antara kelompok-kelompok tersebut mengarah pada polarisasi dan prasangka, hal ini sering mudah terjadi dalam masalah idiologi agama dan politik, bahkan dapat berkembang kepada semua bidang lainnya.

Perkembangan teknologi informasi memberikan keleluasaan orang untuk mengekspesikan pemikiran dan perasaannya melalui media sosial. Seringkali terjadinya konflik di dunia maya diakibatkan oleh sikap negatif kepada kelompok lain yang didasarkan oleh persepsi in groupnya oleh individu sebagai perwakilan dari out group. Kehadiran atau eksistensi out group dipersepsikan sebagai ancaman oleh individu sehingga melahirkan emosi negatif dan berujung pada ujaran kebencian dan perilaku agresi siber lainya (Maxwell, 2016).

Emosi negatif dan kognisi yang diaktifkan oleh ancaman antar kelompok dapat memicu respons perilaku negatif seperti agresi dan perilaku membenci. Pada tingkat individu, respons perilaku negatif terhadap ancaman antar kelompok ini meliputi penghindaran, ketidak sepakatan, tindakan yang tidak bersahabat, kompetisi, penghinaan, perilaku ofensif, dan agresi. Pada tingkat kelompok, respon perilaku negatif terhadap ancaman antara lain balas dendam, demonstrasi, pemberontakan, pembelaan terhadap kelompok ingroup, hukum yang menekan outgroup, dan diskriminasi (Stephan dkk., 2016).

Costello dkk., (2016) dalam penelitianya menyimpulkan bahwa haters itu berawal dari seringnya individu terpapar oleh materi materi pemikiran radikal dan ujaran kebencian secara online, dan sikap yang anti (prasangka, persepsi negatif terhadap kelompok/pemerintah) makin memperkuat orang untuk kian terpapar dengan ujaran kebencian. Materi paling umum digunakan para haters adalah stereotip kelompok karena hampir setengah dari materi negatif berpusat pada ras atau etnis, dan responden cenderung menemukan materi ujaran kebencian itu di situs media sosial (Costello dkk., 2016). Sejalan dengan itu Nitin dkk., (2012) melihat lebih dekat konteks sosial dimana flaming (komunikasi during yang menimbulkan emosi memanas) terjadi di media sosial, dengan latar belakang sosial, agama, dan politik para pelaku. Ia menjelaskan bahwa komunikasi online selama ini telah meningkatkan ekspresi emosi yang bermusuhan, yang disebut flaming. Flaming adalah salah satu bentuk dari komunikasi online di media sosial, yang bersifat ujaran kebencian atau komentar, postingan tuwitan yang memunculkan suasana emosi yang memanas bagi orang yang membacanya. Seringkali komunikasi secara online ini jarang mempertimbangkan persaan orang secara tatap muka sehingga memancing suasana panas.

\section{Komunikasi dalam jejaring (daring)}

Komunikasi daring adalah penyampaian pesan oleh individu sebagai komunikator dengan media online atau bebasis digital atau virtual. Gaya komunikasi berbasis virtual di media sosial menghambat kemampuan kita untuk secara fisik merasakan emosi atau kesusahan orang lain, sehingga menurunkan kemampuan kita untuk berempati dengan lawan bicara atau orang lain. Ketika individu tidak memiliki empati, ia akan mudah melakukan aggresi dan penindasan di dunia maya, seperti; berdebat, mempermalukan, atau mengekspos komentar yang diskriminatif.

Komunikasi yang terputus-putus dan kurangnya kontak mata pada media sosial membuat seseorang mudah mengatasi tekanan pribadi dari orang lain, sehingga emosi seperti rasa bersalah dan rasa malu tidak terjadi. Ini bermasalah karena emosi semacam itu sangat penting dalam hal menginternalisasi empati terhadap orang lain dan mencegah pelanggaran norma sosial (Bilton dkk., dalam Ueberall, 2016). Ketika orang merasa tertekan secara pribadi karena menyakiti perasaan orang lain, mereka memikirkan akibat tindakan mereka dan termotivasi untuk mengubah perilakunya dengan menyesuaikan diri dengan norma. Media sosial menghilangkan proses yang memfasilitasi perasaan malu dan bersalah ini, sehingga sulit untuk berempati dengan orang lain dan belajar norma sosial yang bertujuan untuk bersikap hormat dan baik terhadap orang lain. Ini mungkin dapat menjelaskan mengapa video kekerasan, trolling, flaming dan perilaku menghina, memaki atau membenci terus terjadi di media sosial (Ueberall, 2016).

Beberapa kasus kekerasan atau agresi verbal di internet kadang dilakukan oleh remaja, baik siswa maupun mahasiswa. Penelitian yang dilakukan (Daugird dkk., 2015) menyebutkan bahwa sebuah 
postingan intoleransi dan kefanatikan yang dilakukan seorang mahasiswa di salah satu perguruan tinggi Amerika pada akun media sosial miliknya membuat rekan sesama mahasiswa dan pendidiknya disebuah merasa kesal dan menyayangkan tindakan tersebut. Kasus penyerangan di media online atau agresi siber yang dilakukan remaja di atas mengambarkan bahwa ia tidak memiliki kepekaan sosio-emosional dan keterampilan sosial yang baik. Seringkali remaja terjebak dalam perilaku bermasalah dalm hubungan interpersonal, seperti delinquency, perilaku agresi, bullying, dikaitkan dengan kompetensi sosial yang lebih rendah (Romera dkk., 2017).

\section{Algorima Media Sosial}

Media sosial memiliki algoritma untuk menentukan arus informasi dan implikasi dari konten yang diproduksi. Pada awalnya algoritma di media sosial dibuat untuk memudahkan melacak data, dan tentu saja sebuah kemudahan untuk industri periklanan. Keberadaan algoritma juga mempermudah pengiklan untuk menyasar pasarnya. Namun Pariser (dalam Bozdag, 2015), melihat ada kejanggalan yang berbahaya dari sistem algoritma yang ada dalam layanan media sosial. Menurutnya algoritma akhirnya akan menciptakan sebuah gelembung informasi yang membuat seseorang terisolasi secara intelektual. Maksudnya, ketika seseorang tak pernah melihat sudut pandang berbeda dari orang lain, maka kemungkinan ia untuk berlarut-larut dalam pandangannya sendiri sangat besar. Hal itu dikhawatirkan akan membuatnya mendefinisikan dunia hanya dari satu sudut pandang saja (Hidayah, 2018).

Lebih lanjut Hidayah, (2018) menyatakan bahwa algoritma yang membentuk personalisasi online memutuskan untuk pengguna apa yang akan mereka lihat dan apa yang akan dilindungi dari mereka, menciptakan gelembung filter, yang mengarahkan individu ke ruang gema. Baik gelembung informasi dan ruang gema mewakili fungsi-fungsi penting dalam pembelajaran dan adopsi perilaku menyimpang. Salah satu efek samping negatif dari gelembung informasi adalah bahwa hal itu dapat menyebabkan pengguna terpapar secara tidak proporsional terhadap materi dan asosiasi yang mengkonfirmasi dan memperkuat bias yang sebelumnya mereka miliki. Hasilnya adalah bahwa pengguna menjadi bagian dari ruang gema online, yang ditandai dengan homogenitas dan di mana polarisasi gagasan dapat mengarah pada adopsi sikap yang lebih ekstrem (Amrollahi dan Mcbride, 2019).

Algoritma sepertinya dirancang untuk memberi seseorang lebih banyak dari apa yang mereka pikir dan inginkan dan menjadi personalisasi. Seperti fungsi pencarian Google yang dipersonalisasi, yang berarti bahwa tidak ada pencarian Google dua orang yang sama. Konsep gelembung informasi dan ruang gema dalam algoritma media sosial mengacu pada dampak preferensi dan keinginan kita pada konten dan hasil yang kita lihat di mesin pencari, media sosial, dan platform online lainnya (Wolfowicz, 2015). Perhatian yang signifikan di dunia akademis dan industri telah tertarik pada gagasan ini sejak perkembangannya. Secara khusus, risiko potensial untuk mempersempit sumber informasi untuk pengguna online dan mendorong pengguna ke zona kenyamanan psikologis konfirmasi diri dan mempertaruhkan polarisasi pada tingkat masyarakat telah disebutkan dalam literatur.

\section{METODE}

Metode penulisan artikel ini menggunakan pendekatan kepustakaan atau kajian literatur dengan mengeksprolasi berbagai teori, prinsip, atau gagasan yang digunakan untuk menganalisis dan memecahkan permasalahan yang dirumuskan di latar belakang. Data yang digunakan dalam penelitian ini adalah data sekunder yaitu data yang diperoleh dari hasil penelitian yang telah dilakukan oleh peneliti-peneliti terdahulu. Sumber data diperoleh dari buku dan karya ilmiah yang dipublikasikan pada jurnal (tercetak dan/atau noncetak) yang berhubungan dengan masalah yang menjadi bahasan dalam paper ini.

Artikel ini mengunakan analisis deskriptif, yaitu memaparkan secara sistematis dinamika konsep dan permaslahan, kemudian diberikan pemahaman dan penjelasan agar dapat dipahami dengan baik.

\section{HASIL DAN PEMBAHASAN}

Kasus hate speech online atau ujaran kebencian di Indonesia, muncul sejak media sosial menjadi bagian dari gaya hidup dan kebutuhan masyarakat, namun secara masif perilaku membenci di dunia maya ini terjadi seiring dengan penyelenggaraan pemilu presiden 2009 hingga 2014. Persoalan ini mencapai puncaknya pada pemilihan kepala daerah (Pilkada) DKI Jakarta, dimana dua kubu pendukung calon kepala daerah tersebut berseteru, dengan saling hujat dan saling menjatuhkan, 
bahkan tak jarang dalam perseteruan bermuara pada ujaran kebencian yang menghina etnis, menghujat tokoh agama, pejabat pemerintah, hingga aparat kepolisian. Meskipun Pilkada DKI Jakarta telah selesai dan melahirkan kepala daerah terpilih, kedua pendukung masih saling berseteru (Kementerian Komunikasi dan Informasi, 2014).

Dalam pandangan penulis sendiri, perbedaan agama dan keyakinan bukan satu satunya pemicu prasangaka sosial dan sifat permusuhan (hostility) yang berkembangan ditengah tengah masyarakat kita akhir-akhir ini khususnya media sosial. Sebab boleh saja agamanya sama tetapi berbeda secara sekte dan aliran juga memicu konflik dan perdebatan di jejaring sosial tersebut. Sebut saja dalam Islam sendiri, antara kelompok Islam konservatif yang diwakili oleh Suni Wahabi dan teman-teman Hizbul Tharil Indonesia (HTI) dengan Syiah, Ahmadiyah, dengan kelompok Islam liberal seperti Jaringan Islam Liberal (JIL) dan kelompok Moderat dengan Islam Nusantara dan Islam Rasional lainnya, bahkan dengan kelompok NU sekalipun sering terjadi saling hujat dengan intensitas kebencian antar kelompok. Perbedaan kelompok berdasarkan sektarian di atas adalah persoalan idiologi dan pemikiran keagamaan dan syariat semata, bukan perbedaan agama, seperti Islam dengan Kristen, Katolik, Hindu, Budha dan lainnya.

Selain idiologi keagaaman, idiologi politik seperti sekarang ini sering juga divirall untuk memicu ketegangan antar kelompok, apa lagi di saat pemilu baik pusat maupun daerah. Mulai dengan membahas dasar idiologi partai politik tertentu dan menghubungkanya dengan idiologi besar seperti Komunis, Liberal, Neo liberal, Kapitalis, Negara Islam dan lainnya. Isu keterancaman idiologi yang berkembang saat ini di media sosial terhadap kehidupan berbangsa di Indonesia adalah, bahwa idiologi Pancasila sebagai dasar negara terancam oleh berkembangnya idiologi lain seperti idiologi komunis, idiologi neo liberal dan idiologi negara Islam. Sehingga masing-masing individu mengelompok dan atau dikelompokkan pada salah satu idiologi tertentu berdasarkan pernyataanpernyataan dan komentar-komentarnya di media sosial yang mengarah dan mengindikasikan pemikirannya sejalan dengan aliran dan idiologi tersebut.

Akibat dari kategorisasi identitas tersebut melahirkan pola baru in-group dan out-group dalam bentuk relasi sosial yang baru juga yakni jejaring sosial, dan seringkali ini digunakan oleh individu di antar kelompok untuk saling menghujat, merendahkan satu sama lainya. Hal ini yang dijelaskan (Chau dan $\mathrm{Xu}$, 2007), dalam penelitiannya menyebutkan banyak komunitas blog bermunculan, yang juga memunculkan grup kebencian dan rasis yang turut serta menyebarkan ideology mereka, mengekspresikan pandangannya, dan merekrut anggota baru melalui media blog.

Komunikasi yang terputus-putus dan kurangnya kontak mata pada media sosial membuat mudah mengatasi tekanan pribadi bagi orang lain, menunjukkan bahwa emosi seperti rasa bersalah dan rasa malu tidak terjadi (Bilton, 2015). Ini bermasalah karena emosi semacam itu sangat penting dalam hal menginternalisasi empati terhadap orang lain dan mencegah pelanggaran norma sosial (Muris dan Meesters, 2014). Ketika orang merasa tertekan secara pribadi karena menyakiti orang lain, mereka mempelajari akibat tindakan mereka dan merasa termotivasi untuk mengubah perilaku mereka dan menyesuaikan diri dengan norma. Media sosial menghilangkan proses yang memfasilitasi perasaan malu dan bersalah ini, sehingga sulit untuk berempati dengan orang lain dan belajar norma sosial yang bertujuan untuk bersikap hormat dan baik terhadap orang lain. Ini mungkin menjelaskan mengapa video kekerasan, trolling menyala dan mengomel terus terjadi di media sosial.

Sifat komunikasi di media sosial yang dari satu-kebanyak, akses langsung ke media sosial, komunikasi terputus-putus, dan kurangnya kontak mata di media sosial dapat menyebabkan issuess seperti berbagi, perilaku yang mementingkan diri sendiri atau self interest, peraturan emosional yang buruk, dan rendah empati. Berbeda dengan empati yang berorientasi pada kesejahteraan orang lain self interest atau selfish lebih berorientasi pada kesejah teraan peribadi. Menurut Chiou dkk., dalam (Ueberall, 2016) self-interest, adalah kondisi during dalam konteks komunikasi di media sosial yang membuat individu hanya memiliki frame of reference atau hanya fokus pada diri peribadi ketika membuat pernyataan atau sosial judgments pada kolom komentar atau pernyataan di beranda media sosialnya. Hal ini membuat individu lebih sulit untuk mengambil perspektif orang lain, pada hal ini kunci yang dibutuhkan untuk mengembangkan empati dan pemikiran kritis. Oleh karena itu, self-interest mengurangi kemampuan para cyber atau netizent untuk memahami 
perspektif orang lain dan dikhawatirkan akan mengancam kesejahteraan orang lain. Artinya individu yang mememiliki self interest yang tinggi dalam interaksi onlinennya akan kurang empaty sehingga mudah terjebak dalam perilaku hate speech atau aggresif online.

Self-interest memberi pengaruh kuat pada perilaku, hal tersebut tidak bisa dipungkiri, orang lebih cenderung bertindak sesuai dengan kepentingan pribadi mereka. Menurut Holmes dkk., dalam (Gerbasi dan Prentice, 2013), orang lain akan bertindak sesuai dengan kepentingan pribadinya dan mereka menjelaskan perilaku mereka sendiri yang didorong oleh motif tersebut. Self-interest sebagai upaya mengejar keuntungan dalam domain yang bernilai sosial, termasuk barang material, status sosial, pengakuan, prestasi akademis atau pekerjaan, serta kebahagiaan. Penelitian sebelumnya telah mendokumentasikan perbedaan individu yang sistematis sejauh orang mengidentifikasi pencapaian penanda keberhasilan masyarakat sama pentingnya dalam kehidupan mereka (Gerbasi dan Prentice, 2013).

Menurut Chiou dkk., dalam (Ueberall, 2016) selfinterest, membuat individu hanya memiliki frame of reference diri peribadi ketika membuat social judgments Hal ini membuat individu lebih sulit untuk mengambil perspektif orang lain, pada hal ini kunci yang dibutuhkan untuk mengembangkan empati dan pemikiran kritis. Oleh karena itu, selfinterest mengurangi kemampuan para cyber atau netizent untuk memahami perspektif orang lain dan dikhawatirkan akan mengancam kesejahteraan orang lain. Artinya individu yang mememiliki self interest yang tinggi dalam interaksi onlinenya akan kurang empaty sehingga mudah terjebak dalam perilaku hate speech atau aggresif online.

Menurut (Davis, 1990) empati memiliki aspek kognitif yang disebut dengan perspective taking, yaitu kemampuan individu untuk mengambil sudut pandang orang lain secara spontan. Perspective Taking suatu hal yang amat penting dalam perilaku sosial individu khususnya untuk menjaga keharmonisan interaksi dan relasi antar individu dengan individu atau antar individu dengan out group. Perspective taking dapat menurunkan stereotype dan pandangan buruk terhadap kelompok lain secara lebih efektif dibandingkan dengan melakukan penekanan terhadap stereotype. Konsep perspective taking jika dihubungkan dengan theory of mind, diartikan sebagai kemampuan seseorang dalam menyimpulkan kondisi mental orang lain, memahami dari perspektif mereka, dan dapat pula menginterpretasikan serta memprediksi perilaku selanjutnya dari orang lain.

Penelitian Lesure-Lester, 2000) menunjukkan adanya hubungan positif antara empati dan agresi interpersonal. Tujuan penelitiannya untuk mengetahui apakah empati secara berbeda akan memprediksi agresi interpersonal dan Behavior Compliance Among perilaku pasrah para remaja yang dilecehkan oleh teman sebayanya. Seperti yang diperkirakan, hasil penelitian ini menunjukkan hubungan positif yang kuat antara empati dan tingkat agresi interpersonal yang lebih rendah dan hubungan positif yang kuat antara empati dan tingkat kepasrahan yang lebih tinggi.

Temuan terkini tentang dampak media sosial terhadap empati beragam, pandangan positif menemukan bahwa penggunaan media sosial dapat mendorong empati karena memungkinkan remaja dapat memperluas pemahaman mereka sendiri dan kemampuan mereka untuk mempraktekkan respons empatik. Media sosial, seperti Facebook, memberikan aksesibilitas kepada orang lain secara online, yang memungkinkan individu memiliki kesempatan lebih besar untuk mengungkapkan perasaan simpati mereka yang selama ini biasanya mereka hindari. Karena empati dikembangkan dari waktu ke waktu melalui praktik, perilaku ini akan menjadi lebih kebiasaan.

Pandangan yang berlawanan tentang dampak sosial media terhadap empati adalah bahwa penggunaan yang meningkat dapat menyebabkan desensitisasi sentimen lainnya, yang berakibat pada kurangnya empati. Penggunaan sosial media yang berlebihan dapat membombardir suasana emosi tingkat tinggi atas kejadian negatif dalam kehidupan orang lain yang orang biasanya tidak terpapar, untuk mengimbanginya, seseorang menjadi memblok pada pengalaman emosionalnya, yang dapat mempengaruhi interaksi tatap muka.

Semakin maraknya perang komentar dan opini di media sosial yang memperdebatkan masalah idiologi, ajaran agama, pilihan politik adalah merupakan indikasi masyarakat mengalami desensitifikasi atau menurunnya rasa sensitif terhadap orang lain, dan seakan bentuk akumulasi emosi dari individu terhadap kelompok yang saling berlawanan. Perang komentar tersebut terjadi karena komunikasi dalam jejaring (daring) berjalan secara tidak langsung, antara pihak yang berseteru tidak 
berhadapan langsung secara fisik (Mohseni dan Ragan, 2018).

Dukungan terhadap pandangan di atas diperkuat dari sebuah survei yang hanya menemukan sebagian kecil orang dewasa madia yang mendaftar untuk membantu orang lain sebagai tujuan prioritas dari hidup mereka. Mereka mayoritas lebih mengindikasikan prinsip bahwa untuk menjadi kaya adalah tujuan terpenting dalam hidupnya (Alloway dkk., 2014). Penelitian lainnya tentang perilaku media sosial dan egoisme dari (Wickel, 2015) dengan melakukan survei 12 item pertanyaan kepada 93 mahasiswi perguruan tinggi yang menanyakan apakah perilaku posting selfies di media sosial menjadikan orang semakin narsis dan egois. Studi ini menemukan bahwa $55 \%$ peserta sepakat bahwa posting selfie ke berbagai platform jejaring sosial mendorong narsisisme dan perilaku egois mereka.

Selain itu fenomena ruang gema dan gelembung informasi pada algoritma media sosial kadang tak dapat dipungkiri dapat membuat ekstrimisasi preferensi yang dimiliki seorang netizen. Berawal dari suka atau tidak suka dalam beberapa momen interaksi di media sosial akan menginternalisasi atau menempa pikiran netizen ke arah preferensi ekstrim, muali dari persepsi yang salah tentang orang lain sampai pada sikap prasangka bahkan pada perilaku diskriminasi dan ujaran kebencian. Ruang gema atau echo chamber seorang netizen difasilitasi oleh bantuan gelembung informasi filter bubblenya membuat ruang yang mengkondisikan individu yang tidak hanya menyaring informasi masuk namun juga menggaungkan informasi yang sudah terserap berulang kali. Fenomena ini menjadikan setiap netizen diarahkan menuju kepada "suara-suara" yang sama dengan apa yang diyakininya secara lebih presisi. Rekaman suka dan tidak suka diambil saat netizen beraktivitas melalui klik, like, block, unfollow, unfriend, mute maupun share di media sosial (Söderberg, 2016; Lawless, 2019).

Informasi dan berita menjangkau warga pengguna media sosial (netizen) sebagian besar melalui proses seleksi otomatis dan dipersonalisasi, didorong melalui algoritma yang dirancang dengan cermat. Algoritma tersebut adalah bagian penting dari perkembangan teknologi media sosial dan platform serta lingkungan berbasis internet lainnya, meskipun hanya 29\% orang yang tahu bahwa algoritma bertanggung jawab atas informasi yang muncul di garis waktu dan umpan berita media sosial mereka.
(José, 2019). Algoritma tidak menjamin penyampaian informasi yang seimbang dan netral, penyaringan algoritmik dapat dibiaskan oleh fitur manusia dan teknologi yang menentukan sifat, orientasi, atau asal berita yang disaring. Dalam hal ini, salah satu bahaya terbesar "kecerdasan buatan" mungkin adalah perkembangbiakan algoritma yang bias.

Beberapa peneliti menganggap bahwa fenomena gelembung informasi (filter bubble) sebagai masalah serius bagi demokrasi dan kebebasan informasi di internet dan media sosial. Fenomena ini dapat membatasi akses pengguna ke sumber informasi di luar zona nyaman mereka dan meningkatkan risiko polarisasi pendapat tentang berbagai topik yang banyak melahirkan perdebatan yang tidak sehat karena sangat sulit untuk ditemukan solusi dan titik temunya. Hal tersebut karena setiap kelompok hidup dalam ruang gema sendiri, yang ia yakini sebagai realitas "benar", dan umumnya mereka berjuang untuk mempertahankan keyakinan diri dan kelompoknya dengan menjelekjelekkan kelompok lain. Pada era media sosial dan konten yang gelembung informasi dan dipersonalisasi di ruang gema ini menjadikan individu lebih picik dalam berpikir karena kita semakin jarang mendapatkan informasi di luar grup pilihan kita sendiri (O'Hara dan Stevens, 2004; Menéndez, 2012).

Ruang gema atau echo chamber adalah jaringan orang-orang yang berpikiran sama dan rentan terhadap polarisasi, di mana mereka memiliki pandangan dunia mereka hanya mencerminkan ideologi ekstrim sebuah kelompok atau komunitas ataupun group siber. Mereka dan secara simultan menghalangi pemaparan terhadap kemungkinan dari padangan yang berbeda. Ruang gema adalah tempat di mana frekuensi, durasi, dan intensitas definisi, serta asosiasi itu sendiri pada dasarnya homogen, dengan definisi yang bertentangan hampir tidak ada.

Ketika individu memutuskan untuk terus berada nyaman dalam literature gelembung informasinya akan membuatnya semakin sulit untuk keluar dari dunia yang dipersonalisasi dan mengubah selera serta pendapat mereka. Bahkan konsekwensinya tidak jarang mereka akan gampang terjebak pada berita palsu, ketika mereka mereka memutup diri dari masuknya informasi baru ke dalam gelembung informasinya tersebut. Kondisi seperti ini akan semakin parah pada saat tahun tahun politik. Masyarakat akan mudah terpolarisasi pada 
kelompok-kelompok ekstrim dan saling berhadapan bahkan bermuara pada pergesekan dan konflik sosial yang lebih jauh (Bozdag, 2015; Mohseni dan Ragan, 2018).

Kedua kelompok akan saling serang melalui status, tautan berupa; komentar, ujaran yang bersifat menghina, mencela, mengancam, menteror, mengungkapkan informasi pribadi, bahasa kasar, pelecehan, penghinaan publik melalui postingan yang tidak diinginkan, lewat gambar, dan rekaman video serta lain sebagainya yang merugikan orang yang menjadi korbannya (Bennett dkk., 2011). Penyerangan dan kekerasan di media sosial dapat disebabkan oleh personalisasi web. Media sosial memungkinkan terjadinya gelembung besar (bubble filter) yang membuat pengguna menolak ideologi atau kebenaran lain.

Kondisi ini akan semakin parah ketika pengguna media sosial bersifat anomim atau berada pada indentitas yang samar yang akan membuat seseorang berada pada kondisi deindividualisasi, yakni menurunnya kesadaran diri. Pelaku merasa dirinya tidak dikenali oleh pihak lawan dan merasa nyaman dalam kelompoknya. Selain itu, komentar yang menghina, merusak orang atau pihak lain dianggap sebuah hal yang biasa. Semakin kontroversial status yang ditulis, semakin panas ujaran kebencian yang dibagikan. Tidak sekedar memicu adrenalin masing-masing pihak yang merasa pendapatnya paling benar (Cohen-almagor, 2014).

Secara khusus, polarisasi perdebatan politik di media sosial terjadi akibat konsekuensi utama ketika orang terjebak dalam gelembung informasi yang salah tentang out gruopnya yang dianggap musuh dan mengancam eksistensi kebeadaannya baik sebagai diri peribadi maupun kelompoknya. Goswami (2018) dalam penelitiannya menemukan bahwa penyebaran isu-isu permusuhan yang dibungkus dalam berita palsu (hoax) yang menyulut kebencian telah dipolitisasi di sebarkan di media sosial untuk kepentingan ekonomi dan politik di India. Kebanyakan berita bohong melibatkan berita palsu tentang isu-isu kesukuan, agama, dan ras yang sensitif serta ucapan kebencian yang ditujukan kepada mereka yang berkuasa. Faktanya ditengah masyarakat siber, berita palsu di media sosial bukan hanya postingan yang disukai, dibagikan, atau diikuti, melainkan merupakan teknik ampuh untuk mengalikan propaganda cyber dengan efek dominannya pada sebagian besar pengguna basis media sosial.

\section{PENUTUP}

Perkembangan media sosial memberi perubahan besar pada pola komunikasi antar individu maupun antar kelompok. Perubahan yang terjadi menjadikan ranah dunia kehidupan sebagai dasar pembentukan ruang publik dengan tindakan komunikatifnya yang bersifat virtual dan perbedaan karakteristik komunikasi langsung dengan komunikasi yang berbasis daring tidak jarang terjadi hambatan karena fasilitas algoritma dari media sosial. Keberadaan algoritma dalam layanan media sosial justru membuat polarisasi ditengah tengah masyakat pengguna yang berdampak pada konflik dan prasangka. Pada akhirnya kehadiran internet dan web yang awalnya merupakan alat untuk menghilangkan perbedaan dari ruang lingkup individu, namun karena algoritma yang dibangun justeru akan cenderung memperbesar dan memperkuat prasangka sosial yang kadang terekspresikan pada prilaku ujaran kebencian antar kelompok yang diakibatkan oleh pola komunikasi dari dan ruang gema serta gelombung informasi masing-masing individu pengguna media sosial.

\section{DAFTAR PUSTAKA}

Alloway, T., Runac, R., Qureshi, M., \& Kemp, G. (2014). Is Facebook Linked to Selfishness? Investigating the Relationships among Social Media Use, Empathy, and Narcissism. Social Networking, 03(03), 150-158.

Amrollahi, A., \& Mcbride, N. (2019). How to Burst The Bubble In Social Networks. In the 24th UK Academy for Information Systems International Conference (UKAIS 2019). Oxford, UK.

Bada, M., \& Sasse, A. (2014). Cyber security awareness campaigns: Why do they fail to change behaviour? (July 2014). Proceedings of the International Conference on Cyber Security for Sustainable Society. London: Global Cyber Security capacity Center.

Bennett, D. C., Guran, E. L., Ramos, M. C., \& Margolin, G. (2011). College Students' Electronic Victimization in Friendships and Dating Relationships: Anticipated Distress and Associations With Risky Behaviors. Violence and Victims, 26(4), 410-429.

Bozdag, E. (2015). Bursting The Filter Bubble: Democracy, Design And Ethics. Malatya, CPI Koninklijke Wöhrmann.

Callens, M. (2015). Perceived Threat, Contact and Attitudes towards the Integration of Immigrants . Evidence from Luxembourg. LISER Working papers. 
Chau, M., \& Xu, J. (2007). Mining communities and their relationships in blogs: A study of online hate groups. International Journal of Human Computer Studies, 65(1), 57-70.

Cohen-almagor, R. (2014). Hate on the Internet Hate on the Internet. Annual Review of Law and Ethics, 22, 431-443.

Costello, M., Hawdon, J., Ratliff, T., \& Grantham, T. (2016). Who views online extremism? Individual attributes leading to exposure. Computers in Human Behavior, 63, 311-320.

Daugird, D., Everett, M., Jones, M., Lewis, L., \& White, A. (2015). Diversity and Inclusion in Social Media. Journal of Cases in Educational Leadership, 18(1), 92-102.

Davis, C. M. (1990). What Is Empathy, and Can Empathy Be Taught? Physical Therapy, 70(11 November), 399-407.

Febriawan, I. M., Takwin, B., \& Muhamad, R. (2014). Haters ( not just) Gonna Hate : Hubungan antara Flaming dan Trait Agresi Verbal pada Antifans. Jakarta.

Gerbasi, M. E., \& Prentice, D. A. (2013). The Selfand Other-Interest Inventory. Journal of Personality and Social Psychology, 105(3), 495-514.

Goswami, M. P. (2018). Fake News and Cyber Propaganda: A study of manipulation and abuses on Social Media. Indira Gandhi National Tribal University (MP).

Guimond, S., Dambru, M., Michinov, N., \& Duarte, S. (2003). Does Social Dominance Generate Prejudice? Integrating Individual and Contextual Determinants of Intergroup Cognitions. Personality and Social Psychology, 84(4), 697-721.

Hidayah, A. R. (2018). Persecution Act as Filter Bubble Effect : Digital Society and The Shift of Public Sphere. Jurnal Ilmu Sosial Dan Ilmu Politik, 22(2), 112-126.

Hootsuite. (2017). We are social: Digital in 2017 Global Overview.

José. (2019). Provisional version Social media : social threads or threats to human rights?

Jubany, O., \& Roiha, M. (2015). Backgrounds, Experiences and Responses to Online Hate Speech: A Comparative Cross-Country Analysis. Barcelona.

Kementerian Komunikasi dan Informasi. (2014). Kemkominfo: Pengguna Internet di Indonesia Capai 82 Juta. Berita Kementerian.

Kuwado, F. J. (2015). Bermacam Hal yang Perlu Diketahui soal Edaran Kapolri tentang_Hate Speech_. Kompas.Com.
Lawless, H. (2019). Social Media Echo Chambers \& Democratic Discourse.

Lesure-Lester, G. E. (2000). Relation between empathy and aggression and behavior compliance among abused group home youth. Child Psychiatry and Human Development, 31(2), 153-161.

Martellozzo, Elena Emam, A, J. (2017). Cybercrime and it Victims (first). London And New York: Routledge.

Maxwell, M. (2016). Rage and social media: The effect of social media on perceptions of racism, stress appraisal, and anger expression among young African American adults. Virginia Commonwealth University.

Mohseni, S., \& Ragan, E. D. (2018). Combating Fake News with Interpretable News Feed Algorithms, (Swartout 1983).

Ngwayuh, E. N. (2017). Perceived Threat and Prejudice Towards Immigrants and Russian Minorities Living in Finland. University Of Jyvaskyla.

Nitin, Jaypee Nitin, J., Amit Srivastava, J., \& Ayushi Dwivedi, J. (2012). Behavioural Responses and Proclivity of Facebook Users Towards Flaming. Issues in Information Systems, 13(1), 25-39.

Nitin, J., \& Amit Srivastava, J. (2012). Behavioural Responses and Proclivity of Facebook Users Towards Flaming. Issues in Information Systems, 13(1), 25-39.

O'Hara, K., \& Stevens, D. (2004). Echo Chambers and Online Radicalism: Assessing the Internet 's Complicity in Violent Extremism Kieron O 'Hara (No. EP/J017728/1). Universities of Southampton, Oxford and Edinburgh.

Romera, E. M., Herrera-López, M., Casas, J. A., Ortega-Ruiz, R., \& Gómez-Ortiz, O. (2017). Multidimensional Social Competence, Motivation, and Cyberbullying: A Cultural Approach With Colombian and Spanish Adolescents. Journal of Cross-Cultural Psychology, 48(8), 1183-1197.

Söderberg, B. (2016). Inside the echo chamber: A qualitative study on anti-immigration internet media, political polarization and social trust in a fragmented digital landscape. Södertörns högskola.

Stephan, W. G., Ybarra, O., \& Rios, K. (2016). Intergroup Threat Theory. In T. D. Nelson (Ed.), Handbook Of Prejudice Strerotyping and Discrimination (Second, p. 255). New York, NY 10017: Psychology Press.

Ueberall, R. liggett \& S. (2016). social-media- 
impacts-behavior-norms.pdf. Citizens Crime Commission. Retrieved from www.nycrimecommission.org

Walters, M. A., Brown, R., \& Wiedlitzka, S. (2016). Causes and motivations of hate crime. Equality and Human Rights Commission Research report (Vol. 102). London.

Wickel, T. M. (2015). Narcissism and Social Networking Sites : The Act of Taking Selfies. The Elon Journal of Undergraduate Research in Communication, 6(1), 5-12.

Williams, M., \& Pearson, O. (2016). Hate Crime and Bullying in the Age of Social Media Conference Report. Welsh: Crown.

Wolfowicz, M. (2015). A social learning theory examination of the complicity of personalization algorithms in the creation of echo chambers of online radicalization to violent extremism. Macquarie University. 